\title{
Towards Sustainability in Infrastructural Development: Structural Design of a 330kV Transmission Line Tower in Warri, Nigeria
}

\author{
Julius O Onyeka ${ }^{1}$, Ochonogor Hycent Ifechukwudeni ${ }^{2 *}$ \\ ${ }^{1}$ Professor of Structural Engineering, Imo state University, Owerri \\ ${ }^{2}$ Project Engineer, Ranjy Construction and Foundation (RCF-D) FZE, Lagos
}

*Corresponding Author: Ochonogor Hycent Ifechukwudeni, Project Engineer, Ranjy Construction and Foundation (RCF-D) FZE, Lagos.Email: hycent.ochonogor@gmail.com

\begin{abstract}
Transmission line towers constitute about 50 percent of the cost of the transmission line. The increasing demand for electrical energy can be met more economically by developing different light-weight configurations of transmission line towers. In this work, an attempt has been made to make the transmission line tower more cost effective and structurally stable by changing the geometry (shape) of the tower with respect to its height. A $330 \mathrm{kV}$ single circuit transmission line carrying a square base self-supporting tower was designed. Preliminary sizing of members was done from first principles by obtaining the radius of gyration of both compressive and tension members which resulted in the different sections used. For ease of connection and weight consideration, equal angle sections were used and connection is by bolts. The loading conditions comprise of the tower self-weight and wind load which was done to conform to ANSI/TIA 222G2006 and ANCE Guide-2004. Modeling of the structure was carried out with STAAD pro V8i and analysis to obtain member forces was done both manually and with the aid of computer software. Compression and tension resistant check was carried out with the member forces produced which confirmed that the members selected are adequate while adjustment was made where necessary. This and the bolt provision were done to conform to BS 5950-12000 (Use of structural steel work). The result informed the recommendations made, which included the need to properly consider the tower location before initiating construction.
\end{abstract}

Keywords: Transmission Line, Infrastructural development, Tower design

\section{INTRODUCTION}

Warri is located in the Niger Delta region of Nigeria. Warri is the commercial capital of Delta State with a population of over 700,000 (NPCF, 2015). It is faced with several ecological challenges ranging from flooding, water pollution, air pollution etc.

Electricity, though one of the vital amenities required for the day to day survival of both men and women resident in Warri has been epileptic over the years. Recent intervention by both the Delta State and Federal Government of Nigeria has come to no avail. The problems in the power sector in Delta State can be attributed mainly to the failure of the Transmission Company of Nigeria to effectively transmit power generated from both the Sapele and Ughelli generation stations to the different load points. This is further compounded by the collapse of towers and the non-functionality of some newly erected towers along these lines.

A transmission line tower is a tall structure having a base width of about one-eighth to one-twelfth of the total height of the structure, used to support overhead power lines (Ivovi, 2013). These transmission line towers are usually self-supporting and are capable of resisting all forces due to conductor loads, unbalanced conductor, wind and ice load in any direction. They are also usually square based, with four points of contact with the ground (Donald et al, 2002).

In general, transmission line towers are constructed for power evacuation purposes from generating stations to various load centers. They are constructed with different types of materials including structural steel;fibre glass; concrete - reinforced or pre-stressed; aluminum and wood. However, the most common material is structural steel and in a few cases, reinforced concrete. Although aluminum has the advantage of high strength-to-weight ratio and good corrosion resistance, it is very expensive 
compared to other materials (Preeti and Mohan, 2013). However, where transmission lines cross relatively inaccessible terrain, an aluminum structure can be flown by helicopter directly on top of its foundation, because of the lighter weight (Gopi and Punse, 2007). Transmission line tower can either be constructed as a lattice (self-supporting)or as a mast (tower held up by stays or guys).

Lattice steel tower construction provides great strength, low wind resistance and represents economy in the use of materials. They are designed to withstand enormous loads ranging from wind, selfweight, conductors and accessories etc. as such, whichever consideration or type of tower is chosen for any location, structural stability is the core objective of the design process. Transmission towers are usually triangular or square in cross section, (Preeti and Mohan, 2002). When built as a guyedmast, the entire mast is usually designed to be perpendicular to the plane. According to Donald et al (2002), when built as a tower, the structure is designed to be perpendicular to the ground or may be tapered over part or all of its height. When constructed of several sections which taper exponentially with height, in the manner of the popular Eiffel Tower, the lattice tower is said to be an Eiffelizedone.

Lattice steel towers are usually constructed from rolled angles, cold-formed or bent plate sections, tubes and high-tension wires. The preference for the use of "open" angle sections is for ease of connection with other elements and ease of inspection during service. However, Ivovi, (2013) warns that towers constructed with steel tubes have collapsed in the past due to undiscovered hidden internal corrosion of members.

In determining the tower height and type to be employed at a particular location, the minimum permissible ground clearance, maximum spacing between conductors, vertical spacing between conductors and the vertical clearance between ground wires need to be ascertained first (Murthy and Santhakumar, 2003).

Depending on the considerations, there are different types of lattice transmission towers. The transmission line goes as per available corridors. In the absence of shortest distance straight corridor, transmission line has to deviate from its straight way when obstruction comes. In the light of this, along the total length of a long transmission line, there may be several deviation points (Balland et al, 2009).

Considering the angle of deviation, there are four types of transmission tower:

- A-type tower with angle of deviation between $0^{0}$ to $2^{0}$,

- B-type tower with angle of deviation between $2^{0}$ to $15^{0}$,

- C-type tower with angle of deviation between $15^{\circ}$ to $30^{\circ}$,

- D-type tower with angle of deviation between $30^{\circ}$ to $60^{\circ}$.

As per the force applied by the conductor on the cross arms, the transmission towers can be categorized into:

- Tangent suspension tower and it is generally A-type towers,

- Angle tower or tension tower, sometimes called section tower. All B.C and D types of transmission towers come under this category (Madugula, 2002).

Based on number of circuits carried by a transmission tower, it can be classified as:

- Single circuit tower,

- Double circuit tower,

- Multi circuit tower.

There are also special types of towers, namely:

- River crossing tower,

- Railway/highway crossing tower,

- Transposition tower. 


\section{THE TOWER DESIGN PROCESS}

The general design process is aimed at making the transmission line tower more cost effective and structurally stable by changing the geometry (shape) of the tower with respect to its height. In this light, the linear analysis method was adopted. It implies that the tower is divided into panels within the length of the primary members and loads assigned at each node of the beams to obtain both the nodal displacements and the beam end forces.

Preliminary sizing of members was done from first principles by obtaining the radius of gyration of both compressive and tension members which resulted in the different sections used at various parts of the tower. For ease of connection and weight consideration, equal angle sections were used and connection was done based on bolt conforming to BS5950-1-2000. The loading conditions comprised of lateral load; load arising from wind, gravitational load; load arising from the tower self-weight, appliances, braces etc. which conformed to ANSI/TIA 222-G-2006 and ASCE Guide-2004. STAAD Pro v8 software was used for the 3D modeling, analysis and design of the tower considering all the members of the space truss as primary and secondary members. This was done by the input of the coordinates starting from the leg to get the primary members and then braces are used to connect the legs to each other. This continued up to the peak level followed by the assigning of member properties as obtained in the preliminary sizing. Loads were then assigned (case one and case two). Analysis was then done to obtain the Reactions at the nodes, beam end forces, Beam end displacement and Nodal displacements.

Compression and tension resistant check was carried out with the member forces produced which confirmed that the members selected are adequate while adjustments were made where necessary. Structural drawings were done using Auto CAD software. The eventual output (Tower configuration) meets the ASCE Guide standards.

The design methodology adopted was able to effectively reduce some of the problems usually encountered during structural analysis as the load designation was done at the nodes and not on the members. All loads generated are applied at the nodes in accordance with the specified panels. This also helped in reducing the overall member displacement of the tower which in turn provided a more stable and cost effective tower.

\section{DESIGN PROCEDURE}

The design procedure follows essentially the process in figure 1

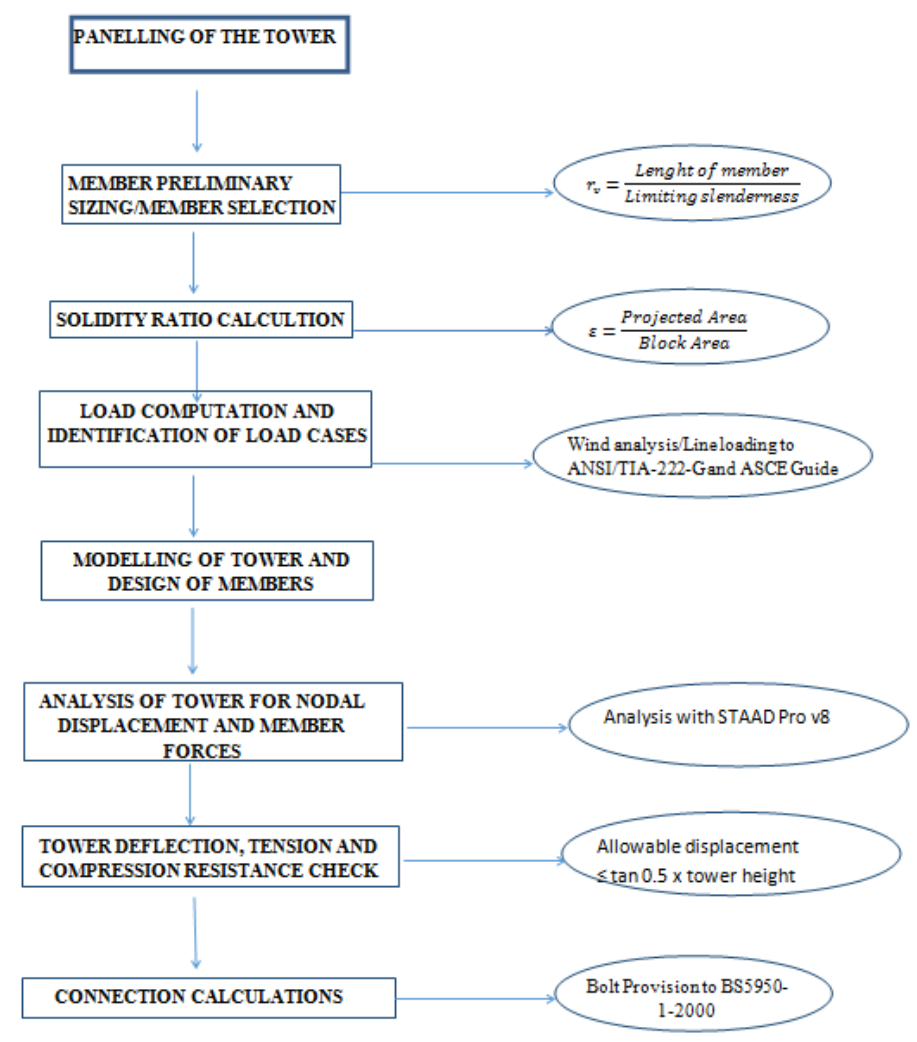

Fig1. Tower design procedure. 
Towards Sustainability in Infrastructural Development: Structural Design of a 330kV Transmission Line Tower in Warri, Nigeria

\subsection{Design Information}

A $330 \mathrm{kv}$ single circuit, suspension transmission line tower with 2 degree angle deviation is considered. The AutoCAD drawing of the tower is shown in Fig 2.The parameters for the design of the transmission line and its components are presented in table 1 and 2.

Table1. Parameters for the transmission line and its components

\begin{tabular}{|c|c|c|}
\hline Description & Parameters & Source \\
\hline Transmission voltage & $330 \mathrm{kV}$ & Specified \\
\hline Tower type & Suspension type A & Specified \\
\hline No. of circuit & Single & Specified \\
\hline Angle of line deviation & $0-2^{0}$ & Specified \\
\hline Basic wind speed & $35 \mathrm{~m} / \mathrm{s}$ & Deltec Nig. Ltd \\
\hline Max temperature & $53^{0} \mathrm{C}$ & Deltec Nig. Ltd \\
\hline Everyday temperature & $40^{\circ} \mathrm{C}$ & Deltec Nig. Ltd \\
\hline Min temperature & $0^{0} \mathrm{C}$ & Deltec Nig. Ltd \\
\hline Insulator type & Suspension type & Specified \\
\hline Weight of insulator disc & $0.36 \mathrm{kN}$ & Specified \\
\hline Weight of ground wire attachment & $0.0075 \mathrm{kN}$ & Specified \\
\hline Wind Span & $450 \mathrm{~m}$ & Specified \\
\hline Weight span & $650 \mathrm{~m}$ & Specified \\
\hline Terrain type considered & Plain 2 & Deltec Nig. Ltd \\
\hline Wind return period & 50years & ANSI/TIA-222-G \\
\hline No. of insulator disc & 18 & Specified \\
\hline No. of conductors & 6 (3pairs) & Specified \\
\hline Slope of tower leg & 40-90 (permissible) & Specified \\
\hline
\end{tabular}

Table2. Parameters for the conductor and ground wire.

\begin{tabular}{|c|c|c|c|}
\hline Description & Conductor & Ground wire & Source \\
\hline Material & ACSR & Earth wire & Specified \\
\hline Diameter & $21.1 \mathrm{~mm}$ & $12 \mathrm{~mm}$ & Specified \\
\hline Coefficient of linear expansion & $0.1935 \times 10^{-4} \mathrm{deg}^{-1}$ & $0.115 \times 10^{-4} \mathrm{deg}^{-1}$ & Specified \\
\hline Modulus of elasticity & $686000 \mathrm{~kg} / \mathrm{cm}^{2}$ & $193300 \mathrm{~kg} / \mathrm{cm}^{2}$ & Specified \\
\hline Unit weight & $2.0 \mathrm{~kg} / \mathrm{m}$ & $0.75 \mathrm{~kg} / \mathrm{m}$ & Specified \\
\hline Max sag & $12 \mathrm{~m}$ & $7 \mathrm{~m}$ & Specified \\
\hline Max tension & $4405 \mathrm{~kg}$ & $1710 \mathrm{~kg}$ & Specified \\
\hline Min tension & $3180 \mathrm{~kg}$ & $1250 \mathrm{~kg}$ & Specified \\
\hline
\end{tabular}

\subsubsection{Load Combinations (Normal condition)}

The two load cases used are as follows:

$1.0 \mathrm{~g}_{\mathrm{k}}+1.6 \mathrm{w}_{\mathrm{k}}$ and $1.0 \mathrm{~g}_{\mathrm{k}}+1.0 \mathrm{w}_{\mathrm{k}}$

Where; $\mathrm{g}_{\mathrm{k}}=$ dead load,

$\mathrm{W}_{\mathrm{k}}=$ live load

\subsubsection{Modeling Coordinate (Design Coordinate)}

The design coordinates are presented in the table 3.

Table3. Design Coordinates

\begin{tabular}{|c|c|c|c|}
\hline \multirow{2}{*}{ Position } & \multicolumn{3}{|c|}{ Axis } \\
\cline { 2 - 4 } & $\mathrm{X}$ & $\mathrm{Y}$ & $\mathrm{Z}$ \\
\hline Ground to Hamper level & -2 & 18 & 0.75 \\
\hline Hamper to cross arm & -2.4375 & 27 & 0 \\
\hline Cross arm to peak level & -3 & 30 & \\
\hline
\end{tabular}

\subsection{Preliminary Sizing of Tower Members}

The member selection was done by determining the radius of curvature along the weaker axis of the members. 
Towards Sustainability in Infrastructural Development: Structural Design of a 330kV Transmission Line Tower in Warri, Nigeria

Radius of curvature along the weak axis $r_{\mathrm{v}}=\frac{\text { Lenght of member } L_{E}}{\text { Limiting Slenderness } \lambda}$

The results are presented in table 4.

Table4. Member selection

\begin{tabular}{|c|c|c|c|c|}
\hline Member & $\boldsymbol{\lambda} \mathbf{( m m )}$ & $\mathbf{L}(\mathbf{m m})$ & rvprovided & Section selected \\
\hline Main leg & 150 & 2000 & 13.33 & $90 \times 90 \times 7 \mathrm{~mm}$ \\
\hline Cross brazes & 200 & 2066 & 10.5 & $60 \times 60 \times 6 \mathrm{~mm}$ \\
\hline Diagonals & 200 & 2012 & 10.6 & $70 \times 70 \times 6 \mathrm{~mm}$ \\
\hline Upper section/Inner leg members & 200 & 2000 & 13.7 & $80 \times 80 \times 8 \mathrm{~mm}$ \\
\hline Horizontal members & - & - & - & $80 \times 80 \times 8 \mathrm{~mm}$ \\
\hline Secondary members & - & - & - & $50 \times 50 \times 6 \mathrm{~mm}$ \\
\hline
\end{tabular}

\subsection{Solidity Ratio (E) Calculation}

This was calculated based on the expression below;

$\varepsilon=\frac{\text { Projected Area }}{\text { Block Area }}=\frac{A_{t}}{A_{g}}$

The results obtained are presented in table 5;

Table5. Solidity ratio

\begin{tabular}{|c|c|c|c|}
\hline Member & $\mathbf{A}_{\mathbf{t}}\left(\mathbf{m}^{\mathbf{2}}\right)$ & $\mathbf{\mathbf { A } _ { \mathbf { g } }}\left(\mathbf{m}^{\mathbf{2}}\right)$ & $\boldsymbol{\varepsilon}$ \\
\hline Panel 1 & 3.574 & 27.560 & 0.13 \\
\hline Panel 2 & 0.841 & 5.500 & 0.94 \\
\hline Panel 3 & 0.806 & 4.389 & 0.16 \\
\hline Panel 4 & 0.776 & 4.389 & 0.18 \\
\hline Panel 5 & 0.776 & 3.834 & 0.20 \\
\hline Panel 6 & 0.723 & 3.278 & 0.22 \\
\hline Panel 7 & 1.590 & 9.000 & 0.18 \\
\hline Panel 8 & 1.509 & 15.000 & 0.10 \\
\hline Panel 9 & 1.288 & 6.455 & 0.20 \\
\hline Panel 10 and 11 & 0.583 & 1.125 & 0.52 \\
\hline
\end{tabular}

\subsection{Load Combination and Identification of Load}

Different loads were considered for this work. These include; Horizontals wind force, Horizontal load on conductor and ground wire, Vertical load on tower members.

\subsubsection{Horizontal Design Wind Force (Fs) Calculation (To ANSI/TIA-222G)}

$\mathrm{Fs}=\mathrm{q}_{\mathrm{s}} \times \mathrm{G}_{\mathrm{h}} \times \mathrm{EPA}$

Where; $\mathrm{q}_{\mathrm{s}}=$ Velocity pressure $\left(\mathrm{N} / \mathrm{m}^{2}\right)$,

$\mathrm{G}_{\mathrm{h}}=$ Gust effect factor,

$\mathrm{EPA}=$ Effective projected area of that section $\left(\mathrm{m}^{2}\right)$.

Load case 1: Load applied normal to the face of the tower.

Load case 2: Load applied at $45^{\circ}$ to the face of the tower

The design wind forces on members are shown in table 6.

Table6. Design Wind Force on tower members

\begin{tabular}{|c|c|c|c|c|c|c|}
\hline \multirow[b]{2}{*}{ Panel } & \multirow[b]{2}{*}{$\mathbf{G}_{\mathbf{h}}$} & \multirow[b]{2}{*}{$\mathrm{q}_{\mathrm{s}}\left(\mathrm{N} / \mathrm{m}^{2}\right)$} & \multicolumn{2}{|c|}{ Load Case 1} & \multicolumn{2}{|c|}{ Load Case 2} \\
\hline & & & EPA $\left(m^{2}\right)$ & $F_{s}\left(k N / m^{2}\right)$ & $\operatorname{EPA}\left(\mathrm{m}^{2}\right)$ & $F_{\mathrm{s}}\left(\mathrm{kN} / \mathrm{m}^{2}\right)$ \\
\hline 1 & 0.85 & 467 & 11.790 & 4.680 & 12.970 & 5.148 \\
\hline 2 & 0.85 & 498 & 2.680 & 1.134 & 2.950 & 1.249 \\
\hline 3 & 0.85 & 523 & 2.480 & 1.103 & 2.780 & 1.236 \\
\hline 4 & 0.85 & 549 & 2.380 & 1.111 & 2.720 & 1.269 \\
\hline 5 & 0.85 & 668 & 2.310 & 1.312 & 2.660 & 1.510 \\
\hline 6 & 0.85 & 619 & 2.100 & 1.233 & 2450 & 1.439 \\
\hline 7 & 0.85 & 626 & 4.880 & 2.597 & 5.560 & 2.958 \\
\hline 8 & 0.85 & 657 & 5.210 & 2.910 & 5.730 & 3.200 \\
\hline 9 & 0.85 & 664 & 3.840 & 2.167 & 4.400 & 2.483 \\
\hline 10 and 11 & 0.85 & 683 & 1.170 & 0.679 & 1.620 & 0.940 \\
\hline
\end{tabular}

International Journal of Constructive Research in Civil Engineering

Page | 14 
Towards Sustainability in Infrastructural Development: Structural Design of a 330kV Transmission Line Tower in Warri, Nigeria

\subsubsection{Horizontal Load on Conductor and Ground Wire (To ANSI/TIA-222-G)}

Wind load on conductor/ground wire $\mathrm{W}_{\mathrm{n}}=\mathrm{q}_{\mathrm{s}} \mathrm{x} \mathrm{d} \mathrm{x}$ horizontal span,

Where; $\mathrm{q}_{\mathrm{s}}=$ Velocity pressure: $=0.657 \mathrm{kN} / \mathrm{m}^{2}$ for conductor and $0.683 \mathrm{kN} / \mathrm{m}^{2}$ for ground wire,

$\mathrm{d}=$ diameter: $=0.021 \mathrm{~mm}$ for conductor and $0.012 \mathrm{~mm}$ for ground wire.

$+\mathrm{W}_{\mathrm{n}}=0.657 \times 0.021 \times 450=6.24 \mathrm{kN}$ (conductor)

$\mathrm{W}_{\mathrm{n}}=0.683 \times 0.012 \times 450=3.69 \mathrm{kN}$ (ground wire)

\subsubsection{Vertical/Gravity Load on Tower members (To ANSI/TIA-222-G)}

Weight of suspension insulators $=36 \mathrm{~kg}=\frac{36 \times 10}{1000}=0.36 \mathrm{kN}$

Vertical load of wire on the structure at one point $=0.36+13=13.36 \mathrm{kN}$ (conductors) $\mathrm{x}$ load factor This is represented in figure 2 .

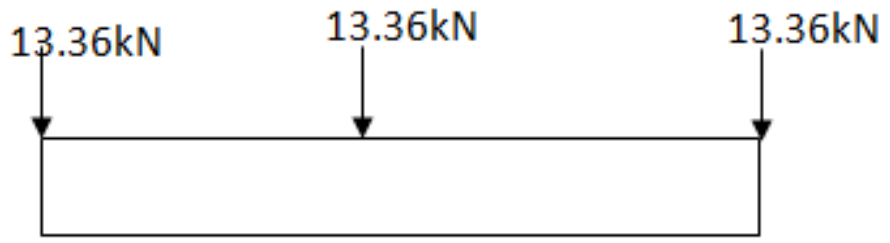

Fig2. Vertical load on tower

On overhead ground wires $=4.9 \mathrm{kN}$

\subsection{Result of Preliminary Analysis}

The results as obtained from the structural design are summarized in tables below;

Table7. Beam End Displacement Summary

\begin{tabular}{|c|c|c|c|c|c|c|c|}
\hline & Beam & Node & L/C & $\begin{array}{c}\text { X } \\
(\mathrm{mm})\end{array}$ & $\begin{array}{c}\mathrm{Y} \\
(\mathrm{mm})\end{array}$ & $\begin{array}{c}\mathrm{Z} \\
(\mathrm{mm})\end{array}$ & $\begin{array}{c}\text { Resultant } \\
(\mathrm{mm})\end{array}$ \\
\hline Max X & 167 & 80 & Load case 2 & $\mathbf{9 . 4 4 2}$ & -3.31 & 10.353 & 14.398 \\
\hline Min X & 442 & 190 & Load case 2 & $\mathbf{- 2 3 2}$ & -40.7 & 2.041 & 235.495 \\
\hline Max Y & 520 & 213 & Load case 2 & -173 & $\mathbf{5 2 . 3 7}$ & -6.339 & 180.537 \\
\hline Min Y & 504 & 208 & Load case 2 & -173 & $\mathbf{- 5 2 . 6}$ & 3.124 & 180.428 \\
\hline Max Z & 167 & 80 & Load case 2 & 9.442 & -3.31 & $\mathbf{1 0 . 3 5 3}$ & 14.398 \\
\hline Min Z & 177 & 83 & Load case 2 & 9.398 & -3.34 & $\mathbf{- 1 0 . 7 7}$ & 14.682 \\
\hline Max Rst & 442 & 190 & Load case 2 & -232 & -40.7 & 2.041 & $\mathbf{2 3 5 . 4 9 5}$ \\
\hline
\end{tabular}

Table8. Reaction at Nodes

\begin{tabular}{|c|c|c|c|c|c|c|c|}
\hline \multirow[b]{2}{*}{ Node } & \multirow[b]{2}{*}{$\mathrm{L} / \mathrm{C}$} & \multicolumn{3}{|c|}{ Force } & \multicolumn{3}{|c|}{ Moment } \\
\hline & & $\begin{array}{c}\mathbf{F X} \\
(\mathrm{kN})\end{array}$ & $\begin{array}{c}\text { FY } \\
(\mathrm{kN})\end{array}$ & $\begin{array}{c}\text { FZ } \\
(\mathrm{kN})\end{array}$ & $\begin{array}{c}\text { MX } \\
(\mathrm{kNm})\end{array}$ & $\begin{array}{c}\text { MY } \\
(\mathrm{kNm})\end{array}$ & $\begin{array}{c}\text { MZ } \\
(\mathrm{kNm})\end{array}$ \\
\hline \multirow[t]{4}{*}{1} & Load case1 & 1.569 & 22.457 & -1.579 & 0.000 & 0.000 & 0.000 \\
\hline & Load case 2 & 13.284 & 148.605 & -9.833 & 0.000 & 0.000 & 0.000 \\
\hline & Combination 1 & 14.853 & 171.062 & -11.412 & 0.000 & 0.000 & 0.000 \\
\hline & Combination 2 & 22.824 & 260.225 & -17.312 & 0.000 & 0.000 & 0.000 \\
\hline \multirow[t]{4}{*}{11} & Load case1 & -1.573 & 22.172 & -1.560 & 0.000 & 0.000 & 0.000 \\
\hline & Load case 2 & 15.743 & -154.388 & 11.342 & 0.000 & 0.000 & 0.000 \\
\hline & Combination 1 & 14.170 & -132.217 & 9.782 & 0.000 & 0.000 & 0.000 \\
\hline & Combination 2 & 23.616 & -224.850 & 16.587 & 0.000 & 0.000 & 0.000 \\
\hline \multirow[t]{4}{*}{33} & Load case 1 & 1.572 & 22.474 & 1.583 & 0.000 & 0.000 & 0.000 \\
\hline & Load case 2 & 14.203 & 158.079 & 11.429 & 0.000 & 0.000 & 0.000 \\
\hline & Combination 1 & 15.775 & 180.553 & 13.012 & 0.000 & 0.000 & 0.000 \\
\hline & Combination 2 & 24.297 & 275.401 & 19.869 & 0.000 & 0.000 & 0.000 \\
\hline \multirow[t]{4}{*}{43} & Load case 1 & -1.569 & 22.131 & 1.557 & 0.000 & 0.000 & 0.000 \\
\hline & Load case 2 & 15.395 & -152.296 & -10.357 & 0.000 & 0.000 & 0.000 \\
\hline & Combination 1 & 13.826 & -130.165 & -8.800 & 0.000 & 0.000 & 0.000 \\
\hline & Combination 2 & 23.063 & -221.542 & -15.015 & 0.000 & 0.000 & 0.000 \\
\hline
\end{tabular}


Towards Sustainability in Infrastructural Development: Structural Design of a 330kV Transmission Line Tower in Warri, Nigeria

Table9. Beam End Forces for member 1 and 2

\begin{tabular}{|c|c|c|c|c|c|c|c|c|}
\hline \multirow[b]{2}{*}{ Beam } & \multirow[b]{2}{*}{ Node } & \multirow[b]{2}{*}{$\mathrm{L} / \mathrm{C}$} & \multirow{2}{*}{$\begin{array}{c}\text { Axial } \\
\mathbf{F x} \\
(\mathbf{k N}) \\
\end{array}$} & \multicolumn{2}{|c|}{ Shear } & \multirow{2}{*}{$\begin{array}{c}\text { Torsion } \\
\mathbf{M x} \\
(\mathbf{k N m})\end{array}$} & \multicolumn{2}{|c|}{ Bending } \\
\hline & & & & $\begin{array}{c}\mathbf{F y} \\
(\mathbf{k N})\end{array}$ & $\begin{array}{c}\mathbf{F z} \\
(\mathbf{k N})\end{array}$ & & $\begin{array}{c}\text { My } \\
(\mathbf{k N m})\end{array}$ & $\begin{array}{c}\mathrm{Mz} \\
(\mathbf{k N m})\end{array}$ \\
\hline \multirow[t]{8}{*}{1} & 1 & Load case 1 & 21.418 & 0.04 & 0 & 0 & 0 & -0.006 \\
\hline & & Load case 2 & 131.16 & 0.202 & 0.058 & 0 & 0 & -0.023 \\
\hline & & Combination 1 & 152.58 & 0.242 & 0.058 & 0 & 0 & -0.03 \\
\hline & & Combination 2 & 231.28 & 0.363 & 0.092 & 0 & 0 & -0.043 \\
\hline & 3 & Load case 1 & -21.23 & -0.022 & 0 & 0 & 0 & 0.069 \\
\hline & & Load case 2 & -131.2 & -0.202 & -0.058 & 0 & -0.116 & 0.428 \\
\hline & & Combination 1 & -152.4 & -0.223 & -0.058 & 0 & -0.116 & 0.497 \\
\hline & & Combination 2 & -131.1 & 0.344 & -0.092 & 0 & -0.185 & 0.754 \\
\hline \multirow[t]{8}{*}{2} & 3 & Load case 1 & 21.105 & -0.037 & 0 & 0 & 0 & -0.078 \\
\hline & & Load case 2 & 130.52 & -0.274 & -0.031 & -0.001 & 0.085 & -0.485 \\
\hline & & Combination 1 & 151.63 & 0.311 & -0.031 & -0.001 & 0.085 & -0.563 \\
\hline & & Combination 2 & 229.94 & -0.476 & -0.05 & -0.001 & 0.136 & -0.853 \\
\hline & 4 & Load case 1 & -20.92 & 0.056 & 0 & -0.001 & 0 & -0.015 \\
\hline & & Load case 2 & -130.5 & 0.274 & 0.031 & 0.001 & -0.022 & -0.066 \\
\hline & & Combination 1 & -151.4 & 0.33 & 0.031 & 0.001 & -0.022 & -0.082 \\
\hline & & Combination 2 & -229.8 & 0.494 & 0.05 & 0.001 & -0.036 & -0.122 \\
\hline
\end{tabular}

\subsection{Final Member Selection}

After the loading and analysis of the tower structure, the members adopted area as follows;

Leg members $=100 \times 100 \times 8 \mathrm{~mm}$

Horizontal members $=80 \times 80 \times 8 \mathrm{~mm}$

Kneel braces on main leg $=70 \times 70 \times 6 \mathrm{~mm}$

Cross braces $=60 \times 60 \times 6 \mathrm{~mm}$

Kneel braces at peak level and cross arm $=50 \times 50 \times 6 \mathrm{~mm}$

\subsection{Bolt Provision for Member Connection}

Leg members 1 and 2 (members in compression)

Diameter of section $=8 \mathrm{~mm}$, force in member $=231.276 \mathrm{Kn}$, Diameter of bolt to be used $=16 \mathrm{~mm}$ (Assumed).

Considering a grade 8.8 counter sunk bolt in $\mathrm{S} 275$ of single shear capacity of $58.9 \mathrm{kN}$

No. of bolt required $=\frac{\text { force in member }}{\text { shear value }}=\frac{231.279}{58.9}=3.9 \sim 4$ no.s

Therefore, provide 4 numbers top and 4 numbers below for leg members. Total 8 no.s of bolt.

Diagonal members 29 to member 2 (members in compression)

Provide 4 no. total for diagonal to leg connection.

\subsection{Tower Deflection Check (To Ance Guide 2004)}

Maximum displacement must be less than or equal to $=\tan 0.5 \mathrm{x}$ tower height

Displacement $=\tan 0.5 \times$ tower height

But maximum displacement $=231.949 \mathrm{~mm}$ from results obtained from design (from beam 442 and node190).

Tan $0.5 \times 30,000=0.00872 \times 30,000=262 \mathrm{~mm}$

Since this is greater than maximum displacement which is $231.949 \mathrm{~mm}$; tower geometry/configuration is adequate $(\mathrm{OK})$ 


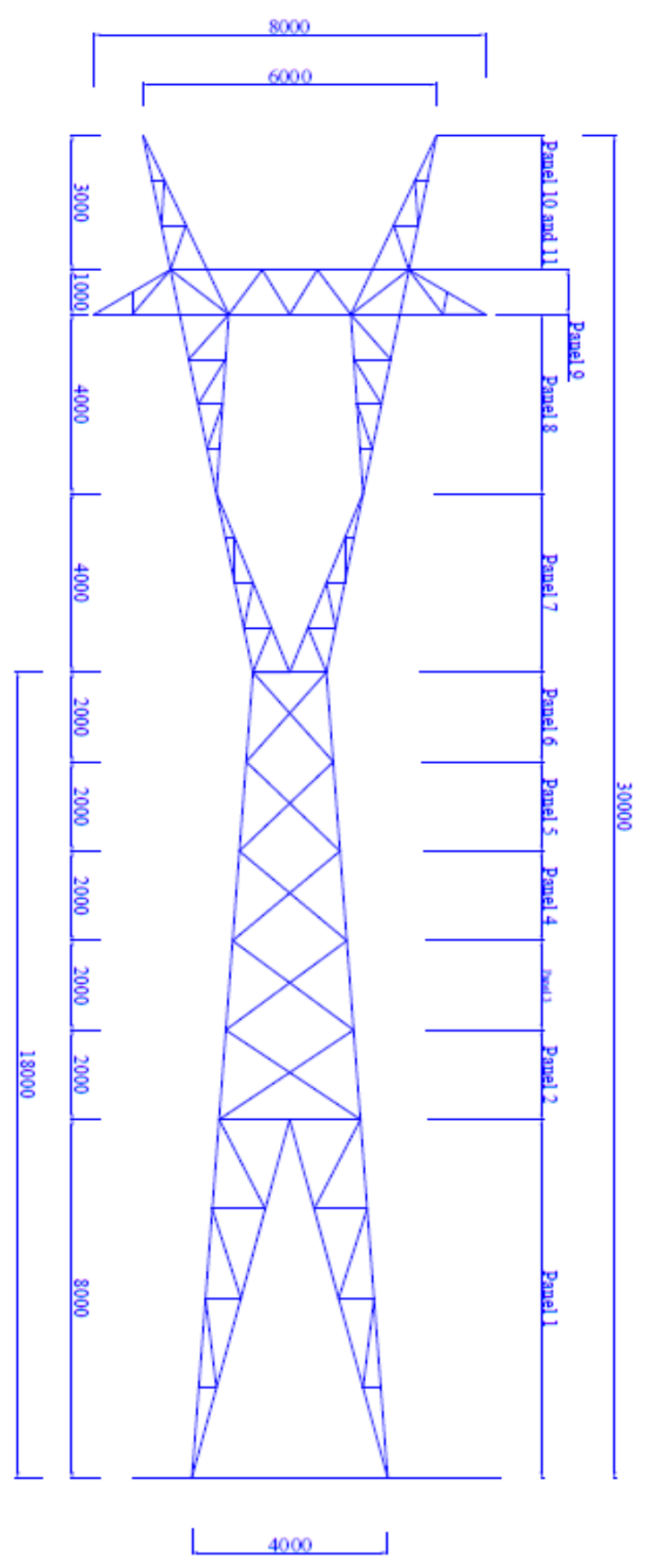

Fig3. The 330kV Transmission Line Tower

\section{CONCLUSiON}

From the results obtained, it is concluded that a tower height of $30 \mathrm{~m}$ will allow for a good clearance from ground level (head room) as recent developments have led to the manufacturing of high vehicles. Also, in areas where road crossing is inevitable, this will not be seen as a problem as the tower height is adequate. In the same vain, fear of electric shock and the negative effect of coronal effect on inhabitants of such areas are also removed.

As transmission line towers are considered to be basically cantilever structures, found to be of light weight and usually subjected to uplift forces as a result of the nature of load on the tower, the steel grade used, S275 (Steel strength of $275 \mathrm{~N} / \mathrm{mm}^{2}$ ) is found to be very efficient and can effectively resist both the compressive and tensile forces produced by the structural members.

Finally, from the design processes and results obtained, it can be concluded that the use of equal angle sections throughout the tower section reduces the out of plane displacement of the tower section. Also, the utilization of each geometric parameter from each section in the design of such sections 
greatly reduces the total (overall) weight of the structure. This further eases the design as the shape tappers from the bottom upwards.

\section{RECCOMENDATION}

From the conclusions drawn, it can be recommended that;

- Tower location should be duly considered before the design and actual construction can take place as the terrain changes directly impact on the outcome of the designprocess.

- Since the cost of tower foundation is reasonably high, the choice of foundation should be given due consideration so as to reduce the overall cost of the tower.

- Also, bolted connection should be adopted in tower construction as weight reduction can be managed by thetower geometry.

\section{REFERENCES}

[1] Balland D. B, Beable B, Brack T. H, Charles H. and Twitty J. (2009). Design Manual for High Voltage Transmission Lines. United State department of Civil Engineering.

[2] Davidson B. and Owens G. W. (2003). Steel Designer's Manual.Sixth Edition, Blackwell Publishers, London.

[3] Donald B, Fink M. and Wayne B. H. (2002). Standard Handbook for Tower Engineering.Eleventh Edition, McGraw-Hill publishers, New York.

[4] Gopi J. andPunse S. (2007). Analysis and Design of Transmission Line Towers. Backwaters press, Dublin.

[5] Ivovi A. I. (2013).Design of Lattice Towers and Masts.Journal for the Center of Advanced Structural Engineering and Studies, Vol 5, No. 3.

[6] Ivovi A. I. (2013).Understanding Structural Steel Work.Journal for the Center of Advanced Structural Engineering and Studies, Vol 5, No. 1.

[7] Madugula M. K. S. (2002). Dynamic Response of Lattice Towers and Masts.America Society of Civil Engineer, Structural Engineering Institute.

[8] Murthy S. S. and Santhakumar A. R. (2003). Transmission Line Structures, McGraw Hill Book Publishing Company, New York.

[9] Preeti J. and Mohan J. (2013).Analysis of Transmission Towers with different configurations.Jordan Journal of Civil Engineering, Vol 7, No. 4.

[10] Visweswan G. R. (2005).Optimum design of Transmission Line Towers.Bargas Publishers, Bangalore.

Citation: Ochonogor Hycent Ifechukwudeni, Julius O Onyeka, "Towards Sustainability in Infrastructural Development: Structural Design of a 330kV Transmission Line Tower in Warri, Nigeria”, International Journal of Constructive Research in Civil Engineering, 6(1), pp. 10-18. DOI: http://dx. doi.org/10.20431/24548693.0601002.

Copyright: (C) 2020 Authors, This is an open-access article distributed under the terms of the Creative Commons Attribution License, which permits unrestricted use, distribution, and reproduction in any medium, provided the original author and source are credited. 